\title{
New urban policies, new forms of social participation? The challenges of the Água Espraiada Urban Consortium Operation in São Paulo, Brazil
}

\author{
Novas políticas urbanas, novas formas \\ de participação social? Os desafios da Operação \\ Urbana Água Espraiada em São Paulo, Brasil
}

Marina Toneli Siqueira [I]

\begin{abstract}
Urban consortium operation is a Brazilian instrument to implement large urban projects. It aims to promote urban services and infrastructure in a specific perimeter by selling construction benefits, which include changes in land uses and building rights. The list of works, their priority and overall development should be debated in management councils representing the diversity of stakeholders involved in the project. Focusing on the Água Espraiada Urban Consortium Operation in São Paulo, this paper analyses the work of its management committee from 2001 to 2014 and exposes disputes among different stakeholders, as well as their strategies and challenges to effective participation. Ultimately, what was supposed to be an arena for democratic decision-making has become an informative arena that legitimizes the project.
\end{abstract}

Keywords: large urban projects; public-private partnerships; social participation; Água Espraiada Urban Consortium Operation; São Paulo/Brazil.

\section{Resumo}

Operação urbana consorciada é um instrumento brasileiro para a implementação de grandes projetos urbanos. Ele objetiva a promoção de serviços e infraestrutura urbana em um perímetro específico através da venda de benefícios construtivos, incluindo transformações de uso do solo e potencial construtivo. A lista de obras, a sua prioridade e o seu desenvolvimento geral deveriam ser debatidos em conselhos gestores representando a diversidade de agentes envolvidos no projeto. Focando no caso da Operação Urbana Consorciada Água Espraiada em São Paulo, esse artigo analiza o trabalho do seu grupo de gestão de 2001 a 2014 e expõe as disputas entre os agentes, suas estratégias e os desafios para a participação efetiva. Como conclusão, o que era para ser uma arena de tomadas de decisão de forma democrática tornou-se uma arena informativa que legitima o projeto.

Palavras-chave: grandes projetos urbanos; parcerias público privadas; participação social; Operação Urbana Consorciada Água Espraiada; São Paulo/Brasil. 


\section{Introduction}

Who is against participation? Or, more specifically, who is against having a voice in the decision-making process that will determine the future of our cities? It is difficult to find anyone who opposes this. In Brazil, even more so. On the one hand, the country has experienced long periods of centralized and authoritarian planning that have not delivered the ambitious goals set for the country's development. On the other hand, the redemocratization process happened in parallel to the country's internationalization, with foreign agents and policy networks redefining local urban planning practices more intensely. It was in this scenario that the main Brazilian urban redevelopment policy emerged.

Urban consortium operation is a mixed instrument that combines land use and financial tools. The policy intends to provide urban services and infrastructure in a specific perimeter of the city by selling construction benefits to investors, which include changes in building rights, land uses and parcels. The strength of the instrument lies in the interest of the real estate market, as it captures the land value created by public works to be reinvested in the targeted area. In addition, the list of public works, their priority, and the overall development of the urban operation are supposed to be discussed and approved collectively in management councils representing the different stakeholders involved in the project - public institutions, professional and business associations, and local residents. Therefore, the instrument is an example of the new type of urban policy in Brazil, which intends to promote urban reform, public participation and more effective tools to deal with the extensive and intense problems of Brazilian cities.

Difficulties emerge when we take into account the great urban inequality in the country and the fact that the perimeters of the most important urban operations include significant numbers of informal communities. Moreover, due to the interest of the real estate market, formal residents suffer pressures from the new developments in the area, which include being the target of displacement strategies and suffering the burdens of the decline in the overall quality of life. It is in the management councils of the urban consortium operations that these conflicts should be settled, including giving priority to investments that benefit the local community and the construction of social housing. However, there have been several accusations that these councils serve to legitimate interests previously set by the public-private partnership and have not been effective in listening and/or responding to popular demands of both formal and informal residents.

Using the case of the Água Espraiada Urban Consortium Operation in São Paulo (AEUCO), this paper analyses the work of its committee and addresses disputes among those groups, the strategies of different stakeholders, and challenges to effective participation and control over these projects. To accomplish this, the study used archival research and document analysis. The methods also included an analysis of the records of the committee's meetings to trace the decision-making process from its enactment in 2001 until 2014. Additionally, the researchers conducted forty-nine semi- 
structured interviews with stakeholders, covering the complexity of the project in terms of its conceptualization, implementation and results. ${ }^{1}$ Field visits and participant observation were also used as complementary methods.

The present paper is organized in five sections, including the present Introduction. The next section presents the context of the emergence of urban consortium operations in Brazil and more specifically in São Paulo, identifying the concepts and cases that influenced their promotion. The third section explains the functioning of the AEUCO focusing on its four main pillars: perimeter; list of works; construction benefits; management council. The fourth section addresses the functioning of the management council from 2001 to 2014, using examples from specific decision-making processes to illustrate difficulties related to the effective participation of representatives of local communities. Finally, the fifth section presents the final considerations. Thus, this paper identifies the AEUCO as a case of urban planning reform in which more competitive, flexible and participatory projects are favored instead of the long-term, comprehensive and centralized plans that have become usual in Brazilian history. Although the specific project of the AEUCO fits the legal requirements of the instrument, there are challenges regarding the functioning of its management council. The data show that decisions made during the meetings were not followed up in the project, and that the council members were asked to vote on previously set arrangements. Specifically, while the construction benefits that promote real estate valorization are sold, public investments that are more competitive are favored over the mandatory provision of social housing and infrastructure to ameliorate the impacts of the project on local communities. In conclusion, what was supposed to be a venue for participation and democratic decision-making has become, mostly, an informative arena that legitimizes the project. Or, as a member of the AEUCO management council mentioned in one of the interviews, "the participation of the society is really just in the discourse".

\section{Reforming urban planning: The emergence of urban consortium operations}

Urban consortium operations are substantially different from traditional urban planning practice in Brazil. Criticism against modernist planning in Brazil started from the diagnosis of an urban crisis that, by no coincidence, occurred simultaneously with the economic and political crisis experienced by the country during the final decades of the twentieth century. In practice, Brazilian modernist urban planning negotiated influences from radical European planners and U.S. policies of land use control to promote high density and strong city centers, while zoning policies would secure property prices. In this sense, zoning was a strategy to guarantee that core areas of cities continued to be exclusive, since they established regulations that restricted their use by impoverished groups (Rolnik, 1997; Villaça, 2001). Therefore, when planning was becoming more present in Brazil, cities experienced the largest increase in urban informality as well. It is no surprise, thus, that modernist planning was also associated with 
the colonial heritage of patrimonialism, given that the state prioritized private interests while clientelist policies guaranteed the survival of the impoverished population in informal housing and jobs. Additionally, the centralized, top-down approach was associated with decades of military dictatorship that ended in the 1980s.

It is also important to understand that public policies in Brazil have to be approved by local legislators to become laws. They are developed by technical departments in the executive branch and must be sent to the city council for approval, leading to heated debates involving elected officials and private agents. The situation was well explained by a former president of São Paulo's EMURB (the Municipal Urbanization Company, currently SP Urbanismo):2 "any proposal you make for São Paulo generates controversy (...). It messes with everybody's pocket. In fact, when you mess with land, you're messing with very large real estate values and do not forget that in an underdeveloped country, the main savings option is land". Therefore, there are high economic and political costs for approving legislation that may curtail the rights of property owners.

The problem led to two main situations. First, because of the endless debates within the city council, urban plans and legislation were automatically approved without vote, based on a legal instrument from the period of the military regime that was still in place in the 1980s. ${ }^{3}$ Second, legislation was simply outdated. For instance, the zoning legislation valid throughout the 1990s had been enacted in 1972. Even taking into consideration that there were piecemeal changes, the delay-ridden process was still dependent on the approval of the city council. Urban policies became identified with centralized and bureaucratic regimes that did not deliver on their promises of economic and social development (Maricato, 2000; Villaça, 2004).

Given the scenario of gridlock in São Paulo's urban planning and in light of the scarce public resources of an economy facing stagflation, partial deindustrialization and the beginning of neoliberal adjustments, urban planning also faced reforms (Fernandes, 2001). Instead of comprehensive plans in a tabula rasa, the new planning ideal was based on fragmented or strategic interventions in the urban space, taking international experiences such as Barcelona as the model of intervention. The mottos were regeneration and synergy, in the expectation that a "benign metastasis" 4 would follow the "surgical" intervention, promoting larger physical and social transformations in the territory (Compans, 2005; Sánchez, 2003). With a clear similarity to the trickledown effect idealized by economists, this model was easily appropriated by neoliberal policies, since it assumes that, by investing in competitive locations, the positive effects would be shared by the entire city. These public benefits would include economic growth, job creation, larger tax bases, diversity of commerce and services, among others. The goals of urban transformation in these projects became closer to the adaptation of cities to a new phase of economic development. This new spatial fix, necessary to the evolution of late capitalism, uses the production of space as a key tool to accumulate capital and promote (relative) location-based advantages (Brenner \& Theodore, 2002; Harvey, 1989). Neoliberal 
urbanism, thus, absorbed national economic and political reforms and transformed cities, such as São Paulo, into experimentation sites for new policy regimes that include public-private partnerships and flexible planning systems. It is within this context that urban operations first emerged in São Paulo.

According to the interviews, Barcelona alongside with urban renewal in the U.S. and great urban projects in European capitals - was one of the sources of inspiration for the instrument urban operation in São Paulo. Accordingly, in the studies for the 1985 Master Plan, urban operations are explicitly justified within the international urban planning scenario:

[...] the urban planning studies developed in the last ten years in light of the international experience indicate that, for the achievement of these goals [urban transformation/redevelopment], the implementation of a category of public development designated as 'urban operation' will be of fundamental importance. (PMSP, 1985a, translation by the author).

The original demand for such adjustments in São Paulo was first transformed into policy in the studies for its 1985 Master Plan, although the plan itself was not approved by the city council and urban operations became a reality only in 1991, with the Anhangabaú Urban Operation (Municipal Law $\left.n^{0} 11090\right) .{ }^{5}$ In this document, urban operations are defined as "the set of interventions in a specific area of the city, with the coordination of the public sector, targeting at relevant goals of the master plan" (PMSP, 1985b, p. 196, translation by the author). From the start, thus, the instrument was defined as a great urban project inspired by the international experience with competitive urban planning. In 2001, the federal urban legislation, the City's Statute, nationalized the policy and defined it in a similar way as:

[...] the aggregation of interventions and strategies coordinated by the Municipal Public Sector, with the participation of owners, residents, permanent users and private investors, with the objective of promoting a specific area's structural change, social improvement, and environmental valorization. (City's Statute, 2001, translation by the author). ${ }^{6}$

It is no surprise that such policy was included in the federal legislation. Public-private partnerships became something common in the Brazilian neoliberal agenda not only with the privatization of the state apparatus in a country in the semi-periphery of the economic system. They became a way of providing more competitive, flexible and participatory projects instead of the long-term, comprehensive and centralized plans that are traditional in Brazilian history and contributed to the gridlock situation of São Paulo, as it was mentioned above. The assumption is that public-private partnerships would create economic growth, become new sources of financial resources and make these projects more efficient. However, what is left unexamined in this discourse is if these benefits are equitably distributed among the partners.

Areas traditionally occupied by the local elites are targeted by competitive investments, but the reality of neoliberal urbanism also includes locations identified as "blighted" or in need of "revitalization," without social policies that could keep the original population 
in place (Arantes, 2012). Therefore, low-income residents, immigrants, and other social groups that do not fit the new image of the city can end up displaced, making gentrification a central feature of these processes of unlocking real estate values to more competitive uses (Hackworth \& Smith, 2001; Smith, 2002). Therefore, these partnerships can become "Trojan Horses" (Miraftab, 2004), by concealing the real interests and final effects of their implementation.

One form of preventing such results is by expanding participatory arenas. With direct and indirect participation, these venues would guarantee accountability and transparency to these projects. Additionally, public participation might become a goal in itself, especially in contexts of a history of centralized, top-down planning as in Brazilian cities coming out of decades of military dictatorship. Therefore, analyzing these policies, such as the urban consortium operation, is more complex than analyzing just the public-private partnership, since we must ask if these new arenas for public participation are really empowering the local population as an exercise of autonomy and effective participation or if they actually reinforce traditional forms of decision-making and their exclusionary effects (Souza, 2003). It is clear that, between the interests of the state, the private sector and local residents, there might be disagreements. The question is if these arenas are able to balance out the uneven relations that were previously set outside them, giving voice to groups that have been underrepresented in urban politics. If that is not the case, the supposedly participatory process functions only to legitimize projects, as a symbolic or formal inclusion, but without much effect on decision-making. Considering the different levels of participation as a form of distributing power, as proposed by Arnstein (1969), this type of community participation and social capital are depoliticized to serve agendas that have already been set, becoming more an informative or, at the most, an advisory arena. That is exactly the conflict that has emerged with the Brazilian urban consortium operations, as it will be explained in the next section.

\section{The state of the art: the functioning of the AEUCO}

This research selected the Água Espraiada Urban Consortium Operation (AEUCO) ${ }^{7}$ as a case study for three main reasons. First, it was enacted on the same year as the federal legislation that normalizes urban planning in Brazil, the City's Statute (2001). As such, it incorporates all of its innovations and requirements. Second, as confirmed by the interviews, it can be considered one of the most complete cases of urban operation implemented in the country and demonstrates the state of the art of the instrument. Finally, not only a considerable time spam has elapsed since its enactment, which enables us to analyze its results, but also it can be considered a successful case of the instrument, given that the public-private partnership has proved to unlock land values and become a new source of funding for urban transformation, as it was intended in the first place.

In terms of functioning, the urban consortium operation employs land use and financial tools to promote redevelopment in 


\section{Image 1 - Location maps - AEUCO}

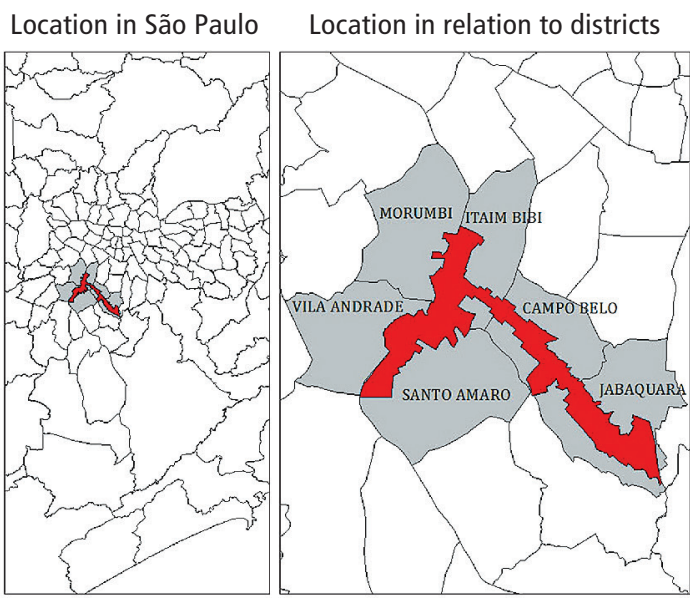

Projection SIRGAS 2000 UTM Zone 23S.

Sources: 1. shapefile for municipalities in the state of São Paulo: IBGE. 2. shapefile for districts: IBGE.

shapefile for river and roads: Diagonal Urbana. shapefile for AEUCO: developed by Marina Toneli Siqueira based on
Água Espraiada Urban Consortium Operation

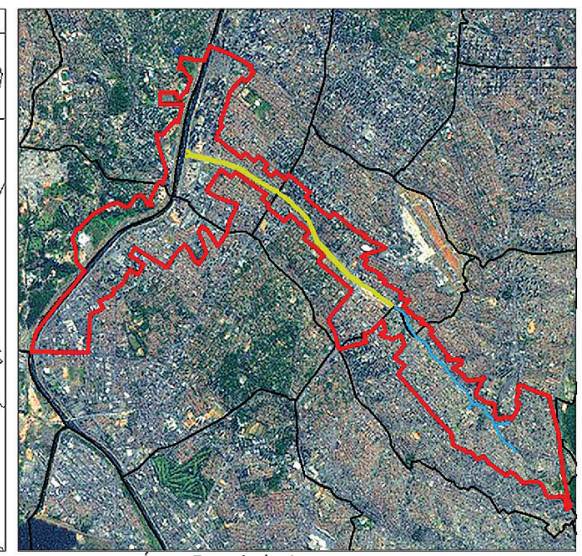

- Agua Espraiada Avenue

- Água Espraiada Stream (non-channelized)

- Água Espraiada Urban Consortium Operation

- District Boundaries a targeted area. It combines four main pillars (Siqueira, 2014). The first one is the definition of a perimeter for the project. It identifies the area where the project will be located and, thus, the area in need of public and private investments. The AEUCO is located in the Southwest sector of São Paulo, with a perimeter that encompasses 1,400 hectares (or 5.4 square miles) in a horizontal T-shape, as seen in Image 1. This extensive area is divided into six sectors: Brooklin, Berrini, Marginal Pinheiros, Chucri Zaidan, Jabaquara, and Americanópolis, as seen in Image 2. These sectors are as diverse as to include: (1) the new business centrality in the Southwest sector of São Paulo, where some of the most important companies in the country, including transnational ones, are located; (2) traditional middle - and high - income neighborhoods, including single-family zoned areas; (3) a great number of informal residents, totaling more than 10,000 households; and (4) a former industrial area, with underutilized large parcels well-served by urban-infrastructure.

Additionally, it is important to mention that the area included in the perimeter of the project has been the focus of public and private investments even before the AEUCO (Ferreira, 2003; Nobre, 2000). The most famous and polemic one is the public work for the construction of the first blocks of the Água Espraiada Avenue (currently Roberto Marinho Avenue), with the partial canalization of the river stream by the same name and the displacement of a local informal community, Jardim Edith. The displaced families ended up on the margins of the most important water reservoir in the city, reinforcing the cycle of urban inequalities, housing informality, 


\section{Image 2 - Perimeter with AEUCO's sectors}

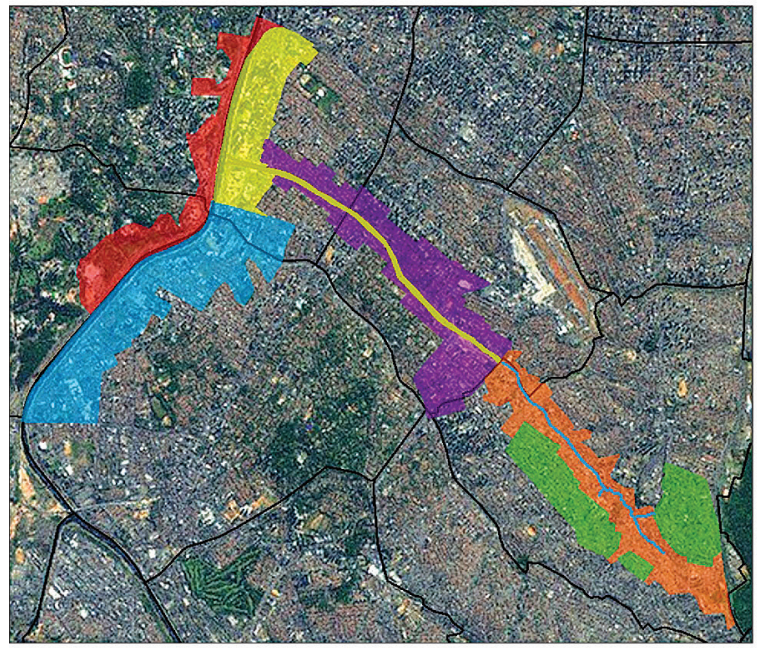

Americanópolis sector

Berrini sector

Brooklin sector

Chucri Zaidan sector

Jabaquara sector

Marginal Pinheiros sector

Água Espraiada Stream (non-channelized)

Água Espraiada Avenue

— Districts boundaries

Projection SIRGAS 2000 UTM Zone 235.

Map developed by Marin Toneli $23 \mathrm{~S}$.

Sources: 1. shapefile for municipalities in the state of São Paulo: IBGE.

2. shapefile for districts: IBGE.

3. shapefile for river and roads: Diagonal Urbana.

shapefile for Água Espraiada Urban Operation:
developed by Marina Toneli Siqueira based on imag

provided by SP Urbanismo.

environmental damage and police violence that is common in Brazilian cities (Fix, 2001). The families that were able to stay in the location, on the other hand, became a symbol of social mobilization. With the support of the Brazilian judicial system and the existence of a local inclusionary zone in the local master plan, they were able to resist displacement and put enough pressure on the City Hall to construct a social housing development in what is now one of the most prestigious locations in São Paulo (Siqueira, 2014). The housing assistance to the communities within the perimeter of the AEUCO is a contentious topic of the second pillar of the AEUCO: the list of works.

The list of works of an urban operation represents the public benefits resulting from the project and essentially justifies its existence. Therefore, it is by identifying the need for public investment in a specific perimeter that an urban operation might be enacted. Conversely, the accomplishment of this list of works is related to the goals of the policy itself. In the case of the AEUCO, the 2001 legislation defined as its objectives:

[...] completion of the road and transportation system, prioritization of public transit, drainage, provision of open space for public use with landscaping, and provision of social housing for the population of slum dwellers affected by the interventions needed. ${ }^{8}$

In order to accomplish this final goal, the legislation secures the relocation of families suffering the impacts of the project within the perimeter of the urban operation, with the implementation of economic and social assistance programs as well as the construction of social housing units, improvements and urbanization of existing communities. 
The third pillar of an urban operation is the partnership with the private sector by selling construction benefits to investors. These benefits can include additional construction potential, changes in land uses and others. In the case of the AEUCO, its original legislation focuses mostly on building rights or additional construction potential. This means that the local zoning legislation establishes a basic and non-onerous floor area ratio to each parcel. To build above that, developers must pay for the additional construction potential, which is limited by a maximum floor area ratio established in view of the present and future investments in services and urban infrastructure. With the urban operation, the resources gathered by selling construction benefits would finance the list of works of the project and all the resources gathered in the operation must be invested only on the list of works approved by the legislation. This is actually one of the major public justifications for using urban operations: the partnership with the private sector would become a way to finance urban investments, which makes the project be financially sustainable. Therefore, the success of the urban operation depends on the interest of the real estate market in buying such construction benefits in the specific urban operation, given that they cannot be used in another project.

As seen on Table 1, the legislation of the AEUCO defines $3,750,000.00$ square meters in the perimeter of the urban operation. ${ }^{9}$ According to a public official working on the project at SP Urbanismo, this calculation was based on both the capacity of the local infrastructure and the budget needed to accomplish the list of works.

Table 1 - Additional building rights (Municipal Law $n^{\circ} 13260$ of 2001) ${ }^{10}$

\begin{tabular}{l|c|c|c}
\hline \multirow{2}{*}{ Sector } & & \multicolumn{2}{c}{ Area by use $\left(\mathrm{m}^{2}\right)$} \\
\cline { 3 - 4 } & Maximum area $\left(\mathrm{m}^{2}\right)$ & $\begin{array}{c}\text { Residential } \\
\text { (minimum 30\%) }\end{array}$ & $\begin{array}{c}\text { Non-Residential } \\
\text { (maximum 70\%) }\end{array}$ \\
\cline { 3 - 4 } Brooklin & $1,500,000.00$ & $450,000.00$ & $1,050,000.00$ \\
\hline Berrini & $250,000.00$ & $75,000.00$ & $175,000.00$ \\
\hline Marginal Pinheiros & $600,000.00$ & $180,000.00$ & $420,000.00$ \\
\hline Chucri Zaidan & $2,000,000.00$ & $600,000.00$ & $2,400,000.00$ \\
\hline SUB-TOTAL & $3,250,000.00$ & $975,000.00$ & $275,000.00$ \\
\hline Jabaquara & $500,000.00$ & $3,250,000.00$ & $350,000.00$ \\
\hline TOTAL & $3,750,000.00$ & $150,000.00$ & $2,625,000.00$ \\
\hline
\end{tabular}


Additionally, the overlapped zoning for the AEUCO, as seen on Table 2, does not establish a height limit in most of the perimeter, while floor area ratios can be up to four, i.e. the final construction can have four times the area of the parcel. ${ }^{11}$ Thus, it is no surprise that one of the major aspects of the AEUCO is the promotion of densification.

Table 2 - Overlapped zoning for AEUCO (Municipal Law $n^{\circ} 13260$ of 2001)

\begin{tabular}{l|c|c|c}
\hline \multicolumn{1}{c|}{ Sector } & Minimum parcel $\left(\mathbf{m}^{2}\right)$ & Floor area ratio & Maximum height $(\mathbf{m})$ \\
\hline Brooklin & $2,000^{12}$ & $\begin{array}{l}4 ; 2 \text { nearby single-family } \\
\text { zoning }\end{array}$ & $\begin{array}{l}\text { no limit; 25 near single-family zones at } \\
\text { Brooklin Velho; } 75 \text { near single-family } \\
\text { zones at Vila Cordeiro }{ }^{13}\end{array}$ \\
\hline Berrini & 1,000 & 4 & no limit \\
\hline Marginal Pinheiros & 1,000 & 4 & no limit \\
\hline Chucri Zaidan & 1,000 & 4 & no limit \\
\hline Jabaquara & 1,000 & 4 & no limit \\
\hline
\end{tabular}

Finally, the minimum parcel size $(1,000$ to 2,000 square meters) seen on Table 2 above imposes a new pattern of occupation that is coupled with stimulus to land assemblage for private investors. ${ }^{14}$ In the AEUCO, for the assemblage of parcels smaller than 2,000 square meters to reach a total area larger than 2,500 square meters, the 2001 legislation provides for a free extra $10 \%$ of the area of the parcel in additional building rights. For total areas larger than 5,000 square meters, the free additional construction potential reaches $20 \%$ of the parcel size (2001 Legislation, Section IV, Article 16). Therefore, by stimulating larger parcels and constructions, the AEUCO promotes a new pattern of spatial production focused on bigger developments. In turn, this new physical occupation requires larger developers, given that it involves more investments in assembling the land, constructing larger developments, and buying construction benefits. Therefore, it can exclude smaller and less capitalized uses.

Another important feature to understand urban consortium operations is that construction benefits can be transformed into bonds, directly connecting urban projects with financial markets. The Certificates of Additional Construction Potential (Certificado de Potencial Adicional de Construção, CEPACs) are financial bonds commercialized in São Paulo's stock exchange market. After they are bought in public auctions, CEPACs can be commercialized in secondary markets, creating a private market for construction benefits in an urban operation. This was only possible after the formalization of the instrument by the City's Statute in 2001 
and the first experience of selling the bonds was in 2004, i.e., nine years after the enactment of the most famous project in São Paulo, the Faria Lima Urban Operation (Municipal Law $\mathrm{n}^{\circ}$ 11732 of 1995). In contrast, the AEUCO was enacted with CEPACs from its start.

Indeed, the AEUCO has been promoting a great urban transformation and has generated a large financial return. Until September 2018, there were five public distributions at BM\&FBOVESPA and nine private distributions (OTC markets). ${ }^{15}$ Table 3 shows that CEPACs for the AEUCO can be considered a success, as they were almost over, reaching the limit of resources to be gathered by selling the bonds and confirming the private developers' interest in the area. Furthermore, the total amount gathered from these distributions is almost $R \$ 3$ billion (or approximately US\$740,740.74), ${ }^{16}$ which means that the public-private partnership accomplished the goal of providing new resources for public works. Discussions about the use of these resources, meanwhile, speak directly about the fourth and final pillar of the AEUCO: the management council.

Consisting of public officials from the municipal government and representatives of the organized civil society, the management council is responsible for "formulating and supervising the urban plans and projects included in the Intervention Program, the general control of the present AEUCO, and proposing revisions of the present legislation". ${ }^{17}$ The establishment of an arena

Table 3 - CEPACs' balance (1st Quarter / 2018)

\begin{tabular}{|c|c|c|c|c|}
\hline & CEPACs offered & CEPACs bought & $\begin{array}{l}\text { Remaining CEPACs } \\
\text { (total: } 3,750,000)\end{array}$ & Amount (R\$) \\
\hline $\begin{array}{l}1^{\text {st }} \text { Public Distribution } \\
\text { (2004-2006 - } 4 \text { auctions) }\end{array}$ & 660,468 & $\begin{array}{r}299,36 \\
(45.33 \%)\end{array}$ & $3,450,632$ & $102,808,720.00$ \\
\hline $\begin{array}{l}2^{\text {nd }} \text { Public Distribution } \\
\text { (2007 - } 3 \text { auctions) }\end{array}$ & 317,781 & $\begin{array}{r}317,781 \\
(100 \%)\end{array}$ & $3,132,851$ & $130,609,991.00$ \\
\hline $\begin{array}{l}3^{\text {rd }} \text { Public Distribution } \\
\text { (2008 - } 1 \text { auction) }\end{array}$ & 186,740 & $\begin{array}{r}186,740 \\
(100 \%)\end{array}$ & $2,946,111$ & $207,281,400.00$ \\
\hline $\begin{array}{l}4^{\text {th }} \text { Public Distribution } \\
\text { (2008-2010 - } 7 \text { auctions) }\end{array}$ & $1,201,841$ & $\begin{array}{r}1,099,680 \\
(91.50 \%)\end{array}$ & $1,846,431$ & $722,923,890.00$ \\
\hline $\begin{array}{l}5^{\text {th }} \text { Public Distribution } \\
\text { (2012 - } 2 \text { auctions) }\end{array}$ & $1,719,339$ & $\begin{array}{r}1,360,338 \\
(79.12 \%)\end{array}$ & 486,093 & $1,731,353,316.00$ \\
\hline $\begin{array}{l}\text { Private Distributions } \\
\text { (2006-2008 - } 9 \text { occasions) }\end{array}$ & 127,092 & $\begin{array}{r}127,092 \\
(100 \%)\end{array}$ & --- & $51,328,532.00$ \\
\hline Total & $4,213,261$ & $\begin{array}{r}3,390,999 \\
(80.48 \%)\end{array}$ & 359,001 & $2,946,305,849.00$ \\
\hline
\end{tabular}


for social participation is an innovation among the previous urban operations in São Paulo and is considered by local public officials as an important aspect of the learning process about the instrument. Confirming the goal of establishing a new source to finance urban investments, the AEUCO management council had been pressuring to start the public works since the first meetings in 2003; however, public officials explained that they would happen only after the first CEPAC auctions. ${ }^{18}$ Therefore, the legislation does, indeed create the formal space for public debate. The problem has been the composition and functioning of the council, which has generated allegations that it would only serve to legitimize the policy, without effective and inclusive participation in the decision-making process. The analysis of works in the AEUCO management council is the focus of the next section.

\section{Effective participation or information? The functioning of the AEUCO management council}

The management council of the AEUCO creates a formal space for public input in the definition of the list of works, uses of resources and any possible revision of the project. Therefore, this is a formal arena created by the AEUCO legislation that, in theory, should fit the level of effective participation, in a partnership with the different stakeholders involved in the project (Souza, 2003). Instead, the practice has been showing an informative or advisory arena with pseudo-participation. The first aspect to consider is its composition. The management council was defined by the 2001 legislation as a parity of seats shared by public institutions (mostly branches of the City Hall) and civil society, with a total of 18 members. The presidency and casting vote belong to the Municipal Department of Urban Development (SMDU), as the coordinator of the AEUCO. Among the seats assigned to the members of the civil society, among the seats assigned to the members of the civil society, two are connected with real estate companies. ${ }^{19}$ Three others, in turn, are designated to important architecture and engineering associations. ${ }^{20}$ It is a common opinion among the representatives of local residents that at least two among these last ones have been consistently supporting the opinions of the real estate market because it would result in more works and commissions to their practitioners.

There are three final seats. Two of them are assigned to low-income residents and/ or social movements; one to a representative of the local informal communities; and one to a national housing movement (União dos Movimentos de Moradia, UMM). Finally, one seat is designated to the Defenda São Paulo organization, which congregates residents' associations from middle - and high-income neighborhoods in the São Paulo Metropolitan Region. Although the formal and informal residents have not established a stable relationship, the two groups confirm that, during the meetings, it is difficult to resist the public institutions and the real estate entities, which are interpreted by these members of the council as acting in consonance.

Between 2001 and 2014, the meetings were closed, i.e., only the official members 
and their alternates could participate, and they were able to invite guests if necessary. Additionally, both middle- and low-income residents registered in the minutes several complaints about lack of information and transparency. In the interviews, it was mentioned that no supporting material was provided before the meetings and, during them, only a slide presentation covered the works, use of resources and future interventions. According to one of the members of the council, "at the meetings, they arrive, present a few numbers and ask for approval. There is nobody there who has sufficient knowledge to say whether those amounts are high, low, should be more, should be less [...]". In this sense, the management council approved the works without appropriate information, which is also matched by requests for more frequent meetings. ${ }^{21}$ Finally, according to members of the council, the minutes were written by hand and there were no voice or image records. Only in the subsequent meeting, months after, a very succinct official transcription was approved. According to some members, this would be a way of confusing the council by not having evidence of what is being decided and/or by whom.

These complaints indeed confirm the concerns of different stakeholders that this social participation arena was used to legitimize the interests of the public institutions and private investors without effective participation of the local communities. For instance, when asked if the management council decides all the expenditures within the AEUCO, the public official from SP Urbanismo made a pause and hesitated to answer 'yes'. When asked about the reason for her lack of confidence, she stated that "it would be naïve to think that everybody is honest. Obviously, the City Hall pressures and the Mayor sends the head of the department to push, to make it happen [...]. But, anyhow, it is more democratic than not having it and the society has to organize itself to be well-represented, to have well-informed representatives".

The members of the council also agree with the opinion that at least there is a channel of information, as one of the members explained that "some advantage it has, you have some information... something [...]." Another member of the council corroborates this opinion, stating that "we go there only to see what we didn't know", referring to decisions previously made outside the council. The consensus is that the council was created to abide by the legislation, as its creation is mandatory. However, these members of the council complain about lack of effective participation in the decision-making process. If the rules are already set and there is no effective change after the members' demands, the problem is the tokenistic level of participation in decisions already made by the public-private partnership.

Three cases that had impacts on both formal and informal residents better illustrate the problems experienced in the AEUCO management council. The first one is the transformations undergone by the original project in 2011, with the approval of Municipal Law $n^{0} 15416 .{ }^{22}$ In its original version, the list of works - the second pillar of the urban operation and its public benefit, as previously mentioned - included canalizing the Água Espraiada stream, finishing the construction of the avenue by the same name (currently 
Roberto Marinho Avenue) and connecting it with a state highway with a 400-meter tunnel. The complementary legislation enacted in 2011, though, changed the original list of works. This was especially important given that, among others, the connection with the Immigrants Highway was transformed into a 2.7-kilometer tunnel and the extension of the Água Espraiada Avenue added a linear park of 600 square meters. These changes had a drastic impact on the functioning of the instrument and generated several polemics, as the list of works considerably exceeded the resources gathered by selling CEPACs. ${ }^{23}$ According to the minutes of the management council's meetings during that year, the City Hall intended to use external funds to finish the works, including the general municipal budget, thus putting an extra burden on public resources.

According to members of the management council, they were not consulted for the approval of the 2011 legislation, although the council has the function of "proposing revisions of the present legislation". ${ }^{24}$ They claim that they were consulted neither about the several studies for the project from 2009 to 2011 nor about the use of AEUCO resources to fund them. Additionally, although public officials state that the council approved the changes in the project, only a list of works was voted in March 2008. According to one of the members, this approval was a way of legitimizing the process, as the public officials asked "what do you want: $A, B, C$ or $D$ ? The list of options is ready." Furthermore, in the new list of works, no new tunnel was included in the proposals by SMDU. Rather, the council approved the general notion of "extension of the Água Espraiada Avenue".
In the minutes of the council, it is possible to see that in its 15th meeting, held in November 2008, the works related to the tunnel and linear park were mentioned after complaints about lack of information on the project and about the issuance of a competitive bidding without the council's approval. The changes in the project also interfered with the previously approved list of works, to which the member from EMURB answered "the adopted solution is comprehensive", while the requests to see the projects were followed by "the project's adaptations are still being made". ${ }^{25}$ These requests were motivated especially by the extensive list of expropriations of both formal and informal residents.

The expropriation impact is an important aspect to consider because, although in all of its previous versions, the project would mostly affect informal communities, the new tunnel was located in middle-income neighborhoods. Hence, while in the 2001 version of the project, the 0.4- kilometer tunnel would cause approximately 230 expropriations of formal houses, the new design would result in more than 1,000 expropriations. It is no surprise, thus, that the middle-income residents started organizing themselves against the project. At this moment, a relationship was established between the formal and informal residents, as both were menaced with displacement. The relationship between the two groups became conflictive, though, after the competitive bidding for the tunnel linked its construction with the social housing units.

The public departments informed that in the bidding process for the construction works, the tunnel was divided into 4 parts, each linked to the construction of 1,000 housing 
units, totaling 4,000 units. This meant that the winning bid for the construction of the tunnel would also have to construct the social housing developments within the perimeter of the urban operation. For the rest of the units, an agreement was signed by the municipal housing authority (SEHAB) and the state housing authority (CDHU) to construct between 4,000 and 6,000 units. Again, members of the management council state that they were not consulted about this agreement and were only informed later on. In any case, by 2013, the informal residents were defending the construction of the tunnel and the linear park as a way of guaranteeing a solution to their housing problems, while the formal residents were against it because of the expropriation of their housing units. A leader of an informal community summarized the conflict at that moment: "it is not one against the other, but it is each one defending his/her space". In April 2019, the tunnel works had not started yet, after having been put on hold in 2013. ${ }^{26}$

The second case related to the functioning of the AEUCO and the role of the management council as a participatory arena is the construction of a monorail line. According to all the interviews, including those with public officials, the line (Linha 17 - Ouro) was first conceived in the context of improving the city's infrastructure for hosting the 2014 FIFA World Cup, although by April 2019 it had not been inaugurated yet. The monorail line would go through the perimeter of the AEUCO to connect existing transit lines and the Congonhas Airport a local stadium. On the one hand, in some interviews it was mentioned that the METRO ${ }^{27}$ and other public institutions related to the transit system at both municipal and state levels had become major decision-makers in the urban planning process in São Paulo. This was justified within an urban scenario of great problems with mobility, several kilometers of traffic jams and lack of suitable options of public transit. On the other hand, residents complained that the high demand for public transit would not be satisfied by the small capacity of a monorail line, and that it could have negative visual and economic impacts on their properties. ${ }^{28}$ Finally, the inclusion of the line in the public works of the AEUCO was plainly dubious.

While representatives of the civil society accused the municipal government of not obtaining the council's consent for the monorail line, officials stated that it was approved within the list of works. By examining the meetings' minutes, it is possible to see a dynamics similar to that of the approval of the tunnel. In this sense, the council approved investments in public transportation within the list of works that was voted in March 2008. However, in the following meeting (July 2008), the monorail line was shown in the presentation by the public departments as one of the investments in public transit. Although there was a map with the location of the line, when members asked for more information, the answer was that studies were still being conducted. Images of the project were presented only in September 2011. This delay and the holding of information further confirms the lack of effective participation, despite the existence of the council.

Finally, it is important to mention that without the approval of the council, funds from the AEUCO were transferred to the state government for the construction of the line. ${ }^{29}$ 
On the one hand, the use of funds was justified by public officials given its partial location within the perimeter of the AEUCO. On the other hand, no resources were made available to the construction of the housing units for the displaced informal residents. Given that the line is not in the AEUCO's list of works - rather, it is a project financed mostly by the state government (through METRO) -, public officials delegated the housing assistance to the state housing department (CDHU). Therefore, there are clear inconsistencies in the discourse about the use of resources that do have an impact on local communities.

The third and final example demonstrates that, in contrast with the demands of the civil society, the most interesting part of the public-private partnership for the real estate market is indeed working. Besides the fact that the construction benefits sold through CEPACs are resulting in a larger development, one of the first public investments in the AEUCO has generated real estate valorization: a new cable-stayed bridge connecting the Água Espraiada Avenue and the Marginal Pinheiros Expressway. In interviews with residents and real estate consultants, it was stated that the bridge has no functionality, which is summarized with sentences such as "it connects nothing to nowhere". However, they all agree that it is the most visible public investment in the AEUCO and has become a symbol of the Global São Paulo. Indeed, the objective was to create a new landmark and this had a major importance in the selection of the design, as stated by the public institution responsible for the project:

[...] the physical characteristics of the area, the transformations experienced with the emergence of numerous intelligent buildings, the work requirements to reduce negative impacts during execution, the evolution of design techniques and works of art, and the need to qualify the urban aesthetics with a singular design that can become a reference to the city - all these factors in conjunction point towards the cable-stayed as the construction option for the project. (PMSP, 2004, p. 31; translated by the author)

In the same document, it was also mentioned that the cable-stayed bridge would equate São Paulo with the most modern cities in the "First World", in which this "design's advances and modernity" had already been used (ibid.). Indeed, aesthetics can be considered the most important aspect of the decision, given that, in a technical report commissioned to the Polytechnic School of the University of São Paulo, the fact that this construction type was more expensive than the traditional successive consoles was emphasized. As it costed $180 \%$ more than originally predicted ( $\mathrm{R} \$ 266$ million compared to the initial R\$147 million), some members of the council are suspicious about the legitimacy of such high costs and the associations between public and private agents in the construction of this symbol of the Global São Paulo. Ultimately, the bridge demonstrates the priority given to certain and more visible investments while, conversely, there are not enough resources to give the mandatory housing assistance to the families affected by the project.

As a general result, the AEUCO represents a more flexible and targeted form of inducing 
urban redevelopment. For the private sector, the construction benefits were sold and used to construct taller and denser structures in one of the most expensive areas of São Paulo, the new and emerging global business centrality. For the public sector, it is a way of gathering resources to accomplish priority projects. Nevertheless, as the representatives of the communities are facing the above-mentioned challenges in the management council, it is no surprise that one former member of the council who resides in a local middle-income neighborhood concluded: "the participation of the society is really just in the discourse".

\section{Final considerations}

Traditional forms of urban planning and service provision are facing times of change. State-centered, top-down, comprehensive and longtime policies are considered outdated not only because of their alleged lack of effectiveness, but also given the current transformations in the economic and political system. The new imperative for cities is to increase their competitiveness to attract investments, companies and residents with capital. Therefore, urban planning should become proactive, flexible and decentralized. In a contradictory movement, though, notions of community participation and social capital can be depoliticized to serve already set reforming agendas. In this sense, the symbolic inclusion of the population in supposedly participatory processes legitimizes projects that can end up with their material exclusion. Great urban projects are in the forefront of this new type of intervention, including Brazilian urban consortium operations.

Urban consortium operations are a form of public-private partnership that aims at the redevelopment of a targeted urban area. The project defines a perimeter of the city in need of investment. To fund the list of public works, construction benefits are sold to investors in the form of financial bonds. To guarantee transparency and public participation in the decision-making process, its management council includes members of public institutions and the civil society. The case of the AEUCO demonstrates, though, that the argument for decentralization, self-governing strategies and more participation has become a way of legitimating the project and previously set investments. The example explored in this paper shows that the public-private partnership has indeed created a new source of resources. However, concerning the list of public works, investments that supposedly increase the city's competitiveness or those related to the interests of the real estate market were favored, while the management council had to vote on projects without sufficient information or lack of transparency.

It is clear that there is not only one type of urban consortium operation in the same way that there is not only one type of great urban project. However, the study of the AEUCO demonstrates the need to improve the quality of the public participation involved in these cases. The most important aspect is that, between the reforming goals of the state, the profit-driven interests of the private sector, and the welfare of the communities, 
there is an unbalanced power relation in which the latter is often overwhelmed by the formers. If the public participation arenas do not discuss these hierarchical positions, there is no guarantee of social inclusion beyond the discourse.

\section{[I] https://orcid.org/0000-0002-1042-8743}

Universidade Federal de Santa Catarina, Centro Tecnológico, Departamento de Arquitetura e Urbanismo. Florianópolis, SC/Brasil.

marina.siqueira@ufsc.br

\section{Notes}

(1) Original Research Protocol \# 2012-0477 by the Office for the Protection of Research Subjects of the University of Illinois at Chicago.

(2) With Municipal Law no 15056 of 2009, EMURB was subdivided into SP Urbanismo, in the Municipal Department of Urban Development (Secretaria Municipal de Desenvolvimento Urbano - SMDU), and SP Obras, in the Municipal Department of Urban Infrastructure and Works (Secretaria Municipal de Infraestrutura Urbana e Obras - Siurb).

(3) In the 1967 Constitution, of the military dictatorship, article 51 established that after a bill prepared by the executive was sent to the legislative, there was a deadline of 40 days for voting it. After this period, it was put in the agenda of discussions for the next 10 subsequent sections. If it still was not voted, it was automatically approved. Following the federal government, several cities enacted similar legislations, including São Paulo. Information available at: http:// www.jusbrasil.com.br/topicos/10626865/artigo-51-da-constituicao-federal-de-1967. Retrieved on: January 19, 2014.

(4) "Benign metastasis" is a term coined by the architect Oriol Bohigas (Arantes, 2012). As the director of the planning department of Barcelona from 1980 to 1984, he was the first to propose interventions on a modest scale focusing on public spaces after the Franco dictatorship (19391975).

(5) This urban operation was transformed into Operação Urbana Centro in 1997 with Municipal Law no 12346. Available at: http://www.prefeitura.sp.gov.br/cidade/secretarias/desenvolvimento_ urbano/sp_urbanismo/operacoes_urbanas/centro/index.php? $p=19620$. Retrieved on: November 1, 2010.

(6) Federal Law no 10257. Available at: www.planalto.gov.br/ccivil_03/Leis/LEIS_2001/L10257.htm. Retrieved on: April 17, 2010. 
(7) The AEUCO was enacted by Municipal Law no. 13260 of 2001 and partially transformed by Municipal Law no 15416 of 2011. Available at: http://www.prefeitura.sp.gov.br/cidade/ secretarias/desenvolvimento_urbano/sp_urbanismo/operacoes_urbanas/agua_espraiada/ index. php?p=19590. Retrieved on: January 14, 2012.

(8) Municipal Law no 13260 of 2001. Available at: http://www.prefeitura.sp.gov.br/cidade/ secretarias/desenvolvimento_urbano/sp_urbanismo/operacoes_urbanas/agua_espraiada/ index.php?p=19602. Retrieved on: January 12, 2012.

(9) This table represents the original legislation of the AEUCO as it was first idealized and effective during the time span of this research (2001-2014). However, Municipal Law no 13260 of 2001 was partially altered by Municipal Law $n=16975$ of 2018, increasing the total additional building rights to $4,850,000 \mathrm{~m}^{2}$ and redistributing the shares for each sector. For instance, in the Jabaquara sector, the building rights diminished from $500,000 \mathrm{~m}^{2}$ to $250,000 \mathrm{~m}^{2}$; in the Brooklin sector, they diminished from $1,500,000 \mathrm{~m}^{2}$ to $1,400,000 \mathrm{~m}^{2}$; and in the Berrini sector, the building rights increased from $250,000 \mathrm{~m}^{2}$ to $350,000 \mathrm{~m}^{2}$. Additionally, the new legislation created a "technical reserve" of $250,000 \mathrm{~m}^{2}$ to be distributed by SP Urbanismo, after consulting the local environment institutions and the AEUCO management council, to the first sector with only $50,000 \mathrm{~m}^{2}$ left in construction potential.

(10) The Americanópolis sector does not have construction benefits.

(11) The only exception are parcels close to the single-family zoning in the Brooklin sector.

(12) Minimum parcel size for the Brooklin sector was altered by Municipal Law no 16975/2018 to 1,000 m².

(13) Maximum height was altered by Municipal Law no 16975/2018 to 18 meters.

(14) It is important to mention that land assemblage is not performed by the public sector in the AEUCO. The policy only opens the possibility for private investors, and they are responsible for all of its steps. Investments by the state are made on the list of works and by using the resources gathered by selling the construction benefits. Therefore, there is a clear distinction between urban operations and urban renewal projects in the United States and Europe, where the state is responsible for these other aspects of redevelopment in addition to infrastructure works (Hall, 2002).

(15) CEPACs can be sold in public distributions during auctions at BMF\&Bovespa or in private distributions to be used directly as a form of payment for works and expropriations. They can also serve as guarantees for financial institutions providing loans to the municipal government for interventions in the urban operation. It is important to mention that all the financial data used in this paper reflects the AEUCO before the transformations of the project enacted by Municipal Law no 16975, approved in September 2018.

(16) On September 30, 2018, 1 US Dollar was equal to 4,05 Brazilian Reais.

(17) Available at: http://www.prefeitura.sp.gov.br/cidade/secretarias/desenvolvimento_urbano/ sp_urbanismo/operacoes_urbanas/agua_espraiada/index.php?p=19602. Retrieved on: August 16, 2011.

(18) The transcriptions of the meetings of the Management Council are available at: http://www. prefeitura.sp.gov.br/cidade/secretarias/desenvolvimento_urbano/sp_urbanismo/operacoes_ urbanas/agua_espraiada/index.php?p=19600. Retrieved on: May 5, 2013, November 24, 2013 and September 26, 2018. 
(19) They are: the local association of companies for public works (Associação Paulista dos Empresários de Obras Públicas - APEOP) and the union of companies for buying, selling, renting, and administering real estate (Sindicato das Empresas de Compra, Venda, Locação e Administração de Imóveis de São Paulo - Secovi). One of these representatives, for instance, made a request to include, in the meetings' minutes, its opposition to housing developments in the area, given the large amount of public subsidy for the units.

(20) They are: the School of Architecture and Urbanism of the University of São Paulo (Faculdade de Arquitetura e Urbanismo da Universidade de São Paulo - FAU/USP), the Institute of Architects of Brazil (Instituto de Arquitetos do Brasil - IAB), and the Institute of Engineering (Instituto de Engenharia).

(21) While the internal regulations determine a quarterly meeting (every 90 days), there were years with one single meeting and others with four.

(22) Available at: http://www.prefeitura.sp.gov.br/cidade/secretarias/desenvolvimento_urbano/ sp_urbanismo/operacoes_urbanas/agua_espraiada/index.php?p=19590. Retrieved on: January $14,2012$.

(23) In terms of costs, the tunnel was estimated at almost $\mathrm{R} \$ 1.6$ billion, plus $\mathrm{R} \$ 752$ million for the linear park with the extension of the Água Espraiada Avenue, and only $\mathrm{R} \$ 380$ million for the social housing units. These amounts do not consider the expropriations that, according to official numbers, would affect 419 constructions for the tunnel and 908 for the linear park and extension of the avenue, expanding the final costs to almost $\mathrm{R} \$ 3.7$ billion. Available at the presentation for the meeting of the management council in September 2011. Available at: http://www.prefeitura.sp.gov.br/cidade/secretarias/desenvolvimento_urbano/sp_urbanismo/ operacoes_urbanas/agua_espraiada/index.php?p=19600. Retrieved on: March 21, 2012.

(24) Available at: http://www.prefeitura.sp.gov.br/cidade/secretarias/desenvolvimento_urbano/ sp_urbanismo/operacoes_urbanas/agua_espraiada/index.php? $p=19590$. Retrieved on: January 14, 2012.

(25) This project faced opposition by the City Council and the municipal auditing agency. It is also interesting to note that one of the reasons to oppose it - the need of a new environmental license - was pointed out by one of the members of the council before the two institutions. However, in a meeting of the management council held in October 2009, the director of EMURB and the representative of Siurb had stated that the projected works complied with the legislation.

(26) In July 2013, in the first year of a new administration (Mayor Fernando Haddad from Workers Party - Partido dos Trabalhadores, PT), the construction of the tunnel was put on hold because of its financial costs.

(27) São Paulo Metro, commonly called the Metro or Companhia do Metropolitano de São Paulo (CMSP), is associated with the State of São Paulo Government. 
(28) The monorail runs on elevated tracks over part of the Água Espraiada Avenue. However, its dimensions are quite pronounced and even the public official from METRO stated that they did not expect this type of structural system. In order to answer to the reactions, METRO carried out a study to demonstrate its impact on the nearby neighborhoods. For that, they hired one of the most famous postmodern architects of São Paulo, which is interpreted again as a form of legitimizing the project. METRO also plans to implement visual blocks in the parts of the line closer to the residences. However, the negative reactions have not diminished. The general association is with an elevated road in downtown São Paulo, popularly known as "big worm" (Minhocão). After its construction, property prices diminished given its visual impact, proximity to the buildings, and noise level. The concern is also with the occupation of the areas bellow the elevated tracks by homeless people and criminals, which could increase urban violence, according to some representatives of the civil society.

(29) The agreement between the municipal and the state government was published in the official gazette on July $07,2010$.

\section{References}

ARANTES, O. (2012). Berlim e Barcelona: duas imagens estratégicas. São Paulo, Annablume.

ARNSTEIN, S. (1969). A Ladder of Citizen Participation. Journal of the American Planning Association, v. 35, n. 4 , pp. 216-224.

BRENNER, N. and THEODORE, N. (2002). "Cities and the geographies of "actually existing neoliberalism". In: BRENNER, N. and THEODORE, N. (orgs.). Spaces of neoliberalism: urban restructuring in North America and Western Europe. Malden, Oxford and Carlton, Blackwell Publishing.

CAIXA (2018). Relatório Consolidado da Operação Urbana Consorciada Água Espraiada. Available at: https://www.prefeitura.sp.gov.br/cidade/secretarias/upload/desenvolvimento_ urbano/sp_urbanismo/AGUA_ESPRAIADA/2018/RelatorioCEF-CVM_OUC_Agua\%20 Espraiada_1\%C2\%BATrim\%202018.pdf. Retrieved on: September 26, 2018.

COMPANS, R. (2005). Empreendedorismo urbano: entre o discurso e a prática. São Paulo, Editora Unesp.

FERNANDES, A. C. (2001). Da reestruturação coorporativa à competição entre cidades: lições urbanas sobre os ajustes de interesses globais e locais no capitalismo contemporâneo. Espaço \& Debates. São Paulo, n. 41, pp. 26-45.

FERreirA, J. S. W. (2003). São Paulo: o mito da cidade global. Tese de Doutorado. São Paulo, Universidade de São Paulo.

FIX, M. (2001). Parceiros da exclusão. Duas histórias de construção de uma "Nova Cidade" em São Paulo: Faria Lima e Água Espraiada. São Paulo, Boitempo.

HACKWORTH, J. and SMITH, N. (2001). The changing state of gentrification. Tijdschrift voor Economische en Sociale Geografie. Utrecht, v. 22, n. 2, pp. 464-477.

HALL, P. (2002). Cities of Tomorrow: an intellectual history of urban planning and design in the twentieth century. Malden, Oxford, Blackwell Publishing. 
HARVEY, D. (1989). From managerialism to entrepreneurialism: the transformation in urban governance in late capitalism. Geografiska Annaler. Series B, Human Geography, n. 71, v. 1, pp. 3-17. Retrieved from JStore on: January 31, 2010.

HOLSTON, J. (1993). A cidade modernista. São Paulo, Cia. das Letras.

MARICATO, E. (2000). "As idéias fora do lugar e o lugar fora das idéias: Planejamento urbano no Brasil”. In: ARANTES, O.; VAINER, C. and MARICATO, E. A cidade do pensamento único: desmanchando consensos. Petrópolis, Vozes.

MIRAFTAB, F. (2004). Public-Private Partnerships: The Trojan Horse of Neoliberal Development? Journal of Planning Education and Research, n. 24, p. 1, pp. 89-101.

NOBRE, E. (2000). Reestruturação econômica e território: expansão recente do terciário na Marginal do Rio Pinheiros. Tese de Doutorado. São Paulo, Universidade de São Paulo.

PMSP [City of São Paulo] (1985a). Dossiê operações urbanas (julho 1983 - janeiro 1985). São Paulo, PMSP/Sempla.

(1985b). Plano Diretor do Município de São Paulo 1985-2000. São Paulo, PMSP/Sempla.

(2004). Suplemento ao prospecto da Operação Urbana Água Espraiada. 1a Emissão de Certificados de Potencial Adicional de Construção - CEPAC. São Paulo, PMSP.

(2018). Relatório Trimestral Operação Urbana Consorciada Água Espraiada. 1o Trimestre/2018. São Paulo, PMSP/SP Urbanismo. Available at: http://www.prefeitura.sp.gov.br/cidade/ secretarias/upload/desenvolvimento_urbano/sp_urbanismo/arquivos/ouae/relatorio_cepac_ agua_espraiada_4tri_2015_cvm_pmsp_spurbanismo.pdf. Retrieved on: September 26, 2018.

ROLNIK, R. (1997). "Planejamento Urbano nos Anos 90: Novas Perspectivas para Velhos Temas". In: RIBEIRO, L. C. de Q. and SANTOS JR., O. A. dos (eds.). Globalização, Fragmentação e Reforma Urbana. Rio de Janeiro, Civilização Brasileira.

SÁNCHEZ, F. (2003). A reinvenção das cidades para um mercado mundial. Chapecó, Argos.

SIQUEIRA, M. T. (2014). In search of gentrification: the local meanings of urban upward redevelopment in São Paulo, Brazil. Tese de Doutorado. Chicago (EUA), University of Illinois at Chicago.

SMITH, N. (2002). New Globalism, New Urbanism: Gentrification as Global Urban Strategy. Antipode, n. 34, v. 3, pp. 429-50.

SOUZA, M. L. (2003). Mudar a cidade: uma introdução crítica ao planejamento e à gestão urbanos. Rio de Janeiro, Bertrand Brasil.

VILLAÇA, F. (2001). Espaço Intra-urbano no Brasil. São Paulo, Studio Nobel/Fapesp/Lincoln Institute.

(2004). "Uma contribuição para a história do planejamento urbano no Brasil”. In: DEÁK, C. and SCHIFFER, S. R. (orgs.). O processo de urbanização no Brasil. São Paulo, Edusp.

Texto recebido em 26/set/2018

Texto aprovado em 26/dez/2018 